\title{
Evaluation of the potential of commercial use of microalgae in the world and in Ukraine
}

\author{
Lesia Pavliukh \\ Department of Ecology, Faculty of Environmental Safety, Engineering and Technologies, National Aviation University, Kyiv, Ukraine \\ Sergii Shamanskyi \\ Department of Research, National Aviation University, Kyiv, Ukraine \\ Sergii Boichenko \\ Faculty of Environmental Safety, Engineering and Technologies, National Aviation University, Kyiv, Ukraine, and \\ Artur Faworski \\ Faculty of Mechanical Engineering and Aeronautics, Rzeszow University of Technology, Rzeszow, Poland
}

\begin{abstract}
Purpose - This paper aims to evaluate of the microalgae potential for commercial application, in particular to conduct experimental study of biogenic compounds removal from sewage waters by microalgae, and to calculate economical benefits from biofertizers and biofuel production.

Design/methodology/approach - Experimental study in the concentration change of nitrogen and phosphorus compounds in the cultivation of Chlorella Vulgaris microalgae in various types of sewage water was carried out.

Findings - The efficiency wastewater treatment by microalgae was confirmed. The economic benefit from the biomass utilization as biofuel production was calculated.

Practical implications - Implementation of wastewater treatment technology with biomass recycling for biofuel and biofertilizers production will minimize the impact on the environment.

Originality/value - As a results of experimental studies, the ability of microalgae to reduce biogenic elements in wastewater was confirmed. Microalgae can be used both for wastewater treatment to biogenic elements removal, such as phosphorous and nitrogen compounds, and biofuel, biofertilizers production. Prospects of the commercial use of microalgae are obvious. They are specially adapted to an environment dominated by viscous forces.
\end{abstract}

Keywords Biofuel, Wastewater, Biofertilizer, Biogenic compounds, Microalgae

Paper type Research paper

\section{Introduction}

The main cause of environmental crisis that is becoming increasingly apparent and large-scale is destructive in nature current production and consumption, i.e. the exploitation of the natural environment without taking into account the vital relationships and interdependencies that have developed in it. This problem relates to all natural resources, in particular to water resources. The problem of water resources depletion is associated with two groups of reasons: firstly, with the continuous increase of water intake for household and domestic needs (quantitative depletion); secondly, with the constant increase of water pollution (qualitative depletion).

So, among the huge amount of pollutants in waste water, in this paper, attention will be paid to biogenic compounds such as nitrogen and phosphorus. Phosphorus in water is in the form of inorganic, organic, organo-mineral compounds and is part of

The current issue and full text archive of this journal is available on Emerald Insight at: https://www.emerald.com/insight/1748-8842.htm

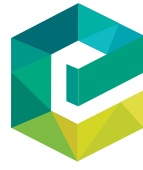

Aircraft Engineering and Aerospace Technology

(C) Emerald Publishing Limited [ISSN 1748-8842] [DOI 10.1108/AEAT-08-2020-0181] the cells of aquatic organisms. To reduce the accumulation of phosphorus in the hydrosphere, it is necessary to do the following: reduce the inflow of phosphorus into water bodies with products of human and animal life, industrial and municipal effluents with detergents that contain phosphorus; reduce the inflow of phosphorus into water bodies from soils (mainly from agricultural lands); develop and implement economically and environmentally friendly technologies for the extraction of phosphorus compounds from water by using the obtained sludge as fertilizer.

\section{Main section}

Today, many different methods and means are used to prevent qualitative and quantitative water resources depletion; they can be conditionally combined into three groups. Preventive (precautionary) measures are aimed at preventing or limiting pollution, clogging and water depletion. They primarily provide for the following:

- the development of schemes for integrated use and water resources protection in a given area;

Received 23 August 2020

Revised 29 September 2020

Accepted 1 October 2020 
- rational location of objects - water users; and

- development of new and improvement of existing production technologies.

Diagnostic measures, as a rule, are aimed at identifying the composition and volume of possible water resources pollution (depletion) and include the following:

- rationing of water supply and drainage;

- standardization of maximum permissible concentrations of various substances in drinking, fishery and other purposes; and

- wastewater discharge control and water bodies ecological condition.

Procedural measures are applied when water bodies are already polluted or depleted and, therefore, are aimed at eliminating existing pollution. This group of measures includes the following:

- organization of wasteless production;

- the use of reverse water supply;

- replacement of water cooling with air;

- purification of snow and drainage waters; and

- imposition of penalties for pollution, clogging and water depletion until the closure of enterprises - pollution sources.

The supply of nutrients to surface waters occurs as because of natural factors (leaching from the layer of soil, precipitation, intra-reservoir processes) and also because of anthropogenic (receipts from industrial and economic domestic wastewater, agricultural land runoff and animal complexes). The most surface water bodies in Ukraine are classified as polluted or much polluted. This condition significantly increases environmental risks. It is the use of water that does not meet quality requirements causes and spreads many infectious and non-infectious diseases.

Increasing concentrations of nitrogen and phosphorus compounds leads to natural waters eutrophication, which is manifested in the phytoplankton biomass increasing, "water blooming", and, as a result, water quality decreasing. This makes impossible to use water for recreation, fishing and domestic needs. The phytoplankton toxins can cause health problems through exposure to the human body after contact with the skin or the use of contaminated water for drinking. That's why waste water treatment from biogenic compounds is so important. Urgent task is to develop effective nutrients removing methods from wastewater at the stage of treatment with waste minimization and the possibility of returning the removed nutrients to economic circulation, as they are valuable elements of mineral fertilizers, especially phosphorus compounds, which are limited in nature (Shamanskyi et al., 2018).

Wastewater treatment requires special treatment facilities and units, which are used to isolate, decontaminate or neutralize contaminants. Domestic wastewater is treated mechanically and biologically. Mechanical treatment is used to extract insoluble substances from wastewater. It is provided by methods such as filtering, settling, filtration and centrifugation. Sewage seepage provides retention of relatively large parts of the pollution, the size of which exceeds $15-20 \mathrm{~mm}$. Water filtration is used to trap the smallest insoluble particles of contaminants in a suspended state. For this purpose, apply sand-gravel filters or special grids. Wastewater treatment from mechanical impurities is also carried out using a hydrocyclone a unit that in the process of rotation of the tank with water as a result of centrifugal forces removes from the water suspended particles of contaminants (centrifugation). In order to intensify the process of mechanical treatment of domestic wastewater, they are aerated, or aeration is combined with settling in clarifiers or biocoagulators. The physico-mechanical method is divided into chemical, physico-chemical and biochemical depending on which method of purification prevails. During chemical treatment, chemical reagents are added to the wastewater, which, as a result of the reaction with the pollutants, contribute to the precipitation or evaporation of the latter. Chemical purification includes coagulation and neutralization. Coagulation is the process of adding coagulant substances to wastewater, which promotes the accelerated release of insoluble and partially soluble substances, which do not precipitate during settling. Coagulation causes the gradual sedimentation of dispersed particles and their release from solution in the form of a precipitate. This process is called sedimentation. Neutralization is a reaction that leads to the destruction of the acidic properties of the solution with the help of alkalis, and alkaline - with the help of acids. Physicochemical and biological methods of water treatment are divided into two groups: regenerative and destructive. The former allows to extract and utilize valuable elements and substances from sewage. Destructive methods involve the destruction of pollutants or their disposal. Regenerative purification methods include: sorption, extraction, evaporation, flotation, ion exchange, electrolysis, crystallization, evaporation and the like. Destructive wastewater treatment is the oxidation of organic matter contained in wastewater. Oxidation and mineralization of organic pollutants as a result of aerobic biochemical processes are the essence of the biochemical method of wastewater treatment.

As was mentioned before conventional sewage water treatment facilities usually apply such methods as mechanical treatment, biological treatment, and biochemical treatment. Using these methods, treatment plants are not always able to provide sufficient purification of the water, especially when pollution content in received sewage water substantially varies. It is advisable to apply additional purification facilities for after treatment of sewage waters. Methods of nature purification are often used for these purposes. In (Gersberg et al., 1986; Kadam et al., 2008), some of the most popular installations are used: special open oxidation ponds, where different aquatic organisms are cultivated; special agricultural tanks filled with hydroponics, where different aquatic plants are grown; special soil filter systems, where different soil plants can grow; and others (Healy and Cawleyb, 2002). One of the promising methods can be considered the use of wastewater for the microalgae cultivation (Sorokina et al., 2012; Sasikanth et al., 2014).

Microalgae are a great biological resource. They are used in various branches of science and technology. Biotechnological investigation of microalgae has been actively developing lately.

Microphytic algae (microalgae) live in various ecosystems. They can be found not only in water but also in earth environments. There are 50000 microalgae species. 
Nevertheless, only approximately 30000 species have been studied (Danilovich, 2012). Microalgae are a broad group of photosynthetic organisms that includes cyanobacteria diatoms unicellular greens and some other species of algae. They can to develop in difficult agro-climatic conditions and to produce a number of useful ones' products fats proteins carbohydrates dyes biologically active compounds, etc.

Microalgae are unicellular species which exist individually, or in chains or groups. Depending on the species, their sizes can range from a few micrometers $(\mu \mathrm{m})$ to a few hundred micrometers. Unlike higher plants, microalgae do not have roots, stems, or leaves. They are specially adapted to an environment dominated by viscous forces. Microalgae, capable of performing photosynthesis, are important for life on earth; they produce approximately half of the atmospheric oxygen (Robyn Williams, 2013) and use simultaneously the greenhouse gas carbon dioxide to grow photoautotrophically. Microalgae, together with bacteria, form the base of the food web and provide energy for all the trophic levels above them. Microalgae biomass is often measured with chlorophyll a concentrations and can provide a useful index of potential production. The standing stock of microphytes is closely related to that of its predators. Without grazing pressures, the standing stock of microphytes dramatically decreases.

Due to microalgae natural metabolism, they are efficient absorbers of nutrients and carbon dioxide, while increasing their biomass. However, the biomass of many strains of microalgae can be used to manufacture many types of products (Naruka et al., 2019). When using this method of wastewater treatment at municipal treatment plants, excess biomass can be directly processed into biogas at treatment plants (Magdalena et al., 2019; Głowacka and Gaduš, 2019; Gonzalez Fernandez et al., 2018; Koyandea et al., 2019; Milledge et al., 2019). This can be done in methane tanks together with excess activated sludge. Biomass can also be processed into liquid motor biofuels of the third generation, or into phosphate and nitrate fertilizers (Raheem et al., 2018; Bhagea et al., 2019; Saad et al., 2019). Many studies are focused on biomass utilization for biofuel production, it can be not only pure fuel from various types of lipid resources also fuels with additives decreasing emissions. Therefore, various ratios of additives (ethanol and pentanol) are blended with biofuel (rapeseed and canolasunflower oil) to form the JET-A fuel blends by using Kay's and Grunberg-Nissan mixing rules. The combustion, performance and emission parameters under different engine loads were examined. Results showed that all the blends logged higher static thrust with an appreciable reduction rate in the consumption of the fuel. Among different fuel blends, R20E (Jet-A 70\% fuel, 20\% Rapeseed and 10\% ethanol) showed 35\% increase in static thrust associated with $41 \%$ reduction in thrust specific fuel consumption. Moreover, the blends R20E and CS20E (Jet-A fuel 70\%, Canola-Sunflower $20 \%$ and $10 \%$ ethanol) indicated $24 \%$ and $10 \%$ increase in thermal efficiency, respectively, owing to the influence of ethanol concentration and higher oxygen content. In addition, these fuel blends generate less emission of environmental unfriendly harmful gases, including $\mathrm{NOx}, \mathrm{CO}$ and $\mathrm{HC}$, compared to neat Jet-A fuel (Manigandan et al., 2020).

The analysis of optimum engine conditions operating under hydrogen and multiwall carbon nanotubes (MWCNTs) blends using the Taguchi L16 approach were examined. The effect of hydrogen $(10 \%, 20 \%$ and $30 \%)$ and MWCNTs (30, 50 and $80 \mathrm{ppm}$ ) with different fuel blend proportions were evaluated at different engine loads of $25 \%, 50 \%, 75 \%$ and $100 \%$. Results revealed that the L16 orthogonal array was a suitable method to find the optimized working conditions of the diesel engine for higher performance and less emission of $\mathrm{NOx}, \mathrm{HC}, \mathrm{CO}$, and $\mathrm{CO}_{2}$. Compared to neat diesel, the addition of hydrogen and MWCNTs reduces the emission with improved brake thermal efficiency. Moreover, results showed improved brake power by $13 \%$ and reduced brake specific fuel consumption by $8 \%$ at full engine load conditions. $22 \%, 20 \%, 8 \%$, and $47 \%$ emission reductions of $\mathrm{HC}, \mathrm{NOx}, \mathrm{CO}$, and $\mathrm{CO}_{2}$ were observed due to the influence of hydrogen and MWCNTs (Manigandan et al., 2020).

The effect of biofuel blend such as butanol, jatropha methyl ester, soya methyl ester and rapeseed methyl ester as an additive for the aviation fuel was assessed (Milledge, J.J., et.al., 2019). In addition to the blends, the nanoparticle $\mathrm{TiO}_{2}$ of $3 \%$ is added to the biofuel. The nanoparticle mixed at the concentration of $300 \mathrm{ppm}$ by ultrasonication process. The fuel Jet A, B27T, J27T, S27T and R27T are investigated for combustion and emission characteristics for various throttle settings in micro gas turbine engine. Addition of additives improves the ultimate property of the fuel by reducing the kinematic viscosity. The fuel blend B27T reports $25 \%$ increase in total static thrust and $22 \%$ reduction in thrust specific fuel consumption. From the results it is evident that, all fuel blends showed a significant reduction in emission values owing to high oxygen content. In addition, the thermal efficiency of the B27T and J27T is improved appreciably to $30 \%$ and $10 \%$ higher than Jet A fuel owing to the influence of the nanoparticle $\mathrm{TiO}_{2}$. On the other hand, the emissions such as $\mathrm{CO}$ and NOx reduced drastically up to $70 \%$ and $45 \%$, respectively.

Authors (Manigandan et al., 2020).) have evaluated the influence of Zinc oxide and Titanium dioxide nanoparticles addition in hydrogen-corn blended biodiesel combustion performance and exhaust emission using a dual direct-injection compression-ignition engine. 5\% of Zinc oxide and Titanium dioxide were mixed with corn-vegetable oil methyl ester under ultrasonication. Results revealed that the addition of nanoparticles improved the Brake power by $22 \%$ (Titanium dioxide) and $4 \%$ (Zinc oxide). Consequently, $18 \%$ and $15 \%$ reduction in brake specific fuel consumption indeed at $50 \%$ load was compared to neat diesel. Furthermore, the addition of nanoparticles also resulted in a reduction of emission values of $37 \%$ and $26 \%$ in hydrocarbon, $26 \%$ and $36 \%$ for carbon monoxide, $19 \%$ and $15 \%$ in nitrogen oxide and followed by $13 \%$ and $8 \%$ of smoke opacity. Therefore, the results proved that hydrogen-corn biodiesel blended with nanoparticles additive reports a positive effect on compression-ignition diesel engines without major modifications in engine.

The next culture can be recommended for cultivating, which have percentage of lipids in them (Shamanskyi and Boichenko, 2016, 2018): •Botryococcus braunii - 25\%-85\%; •Neochloris oleoabundans - 35\%-54\%; •-Stichococcussp - 40\%-59\%; -Nannochloropsissp - 31\%-68\%; •Dunaliella tertiolecta - 36\%$42 \%$; $\bullet$ Dunaliella salina $-16 \%-44 \%$; $\bullet$ Haematococcus pluvialis 25\%-45\%; •Scenedesmus dimorphus - 16\%-44\%;•Prymnesium parvum - 22\%-38\%; - Tetraselmis suecica - 20\%-30\%; 
-Chlorellasp - 28\%-32\%; •Chlorella vulgaris - 14\%-22\%; -Isochrysis galbana-22\%-38\%; • Euglena gracilis - 14\%-20\%.

Usually about $20 \%-30 \%$ of the total production expenses for microalgae production is related to harvesting the biomass (Harun et al., 2011). The main problems in harvesting are the low biomass concentration in the open-pond cultivation system and the small cell size that makes the separation process consumes a great deal of energy. Common methods of harvesting microalgae biomass include: coagulation, flocculation (or sedimentation), flotation (Harun et al., 2011), centrifugation (Molina Grima et al., 2003), membrane filtration (Lourenco et al., 2002; Feofilova et al., 2010), and ultrasonic separation (Bosma et al., 2003).

Centrifugation is regarded as the most efficient method to harvest the biomass using mechanical forces, but their application in large-scale is limited because of the energy costs. Centrifugation can be cost-effective but it requires a two-step process. The typical concentration of algae in open pond cultivation is approximately $300 \mathrm{mg} / \mathrm{L}$. Continuous-flow centrifuges work best if the source water has at least $1 \%-3 \%$ solids. Gravity settling or dissolved air floatation is two simple methods to achieve the desired solids concentration. Membrane filtration has been applied in wastewater treatment involving removal of microalgae cell, which suffers some problems such as bio-fouling and also it is not cost-effective for large-scale biofuel production. Recently, ultrasonic separation (Varfolomeev et al., 2010) and electro-coagulation-flocculation (Vandamme et al., 2011) have been exploited for microalgae harvesting. Promising laboratory-scale results show that these methods are effective and have low-power consumption comparing to centrifugation, but full-scale testing is still in needed to evaluate their cost and performance. After harvesting, the next major challenge is the de-watering the concentrated biomass. Usually, $90 \%$ of the post-harvest weight of the microalgae paste is water which needs to be reduced below $50 \%$ by weight for efficient oil extraction (Reijnders, 2008). Water is removed by heating the biomass that could consume a great amount of energy. However, this process often uses waste heat from power plants to reduce the cost. It is crucial to minimize water contents after harvesting process to decrease energy demand and increase downstream extraction and fuel conversion efficiency.

The ability of microalgae to reduce nitrate and phosphorus levels is widely discussed in the literature and the ability to use this property to treat wastewater waters from biogenic elements (Veber, 1984; Ghorbunova, 2007). At the same time, the issue of assimilation of phosphorus compounds has been studied much less.

Bio-treatment with microalgae is particularly attractive because of their photosynthetic capabilities, converting solar energy into useful biomasses and incorporating nutrients such as nitrogen and phosphorus causing eutrophication. This fascinating idea launched some 55 years ago in the USA by Oswald and Gotaas (1957) has since been intensively tested in many countries. According to the various study, the nutrients removal efficiency of microalgae based wastewater treatment system is very high as it removes $78 \%-99 \%$ of Nitrogen and Phosphorus (W. J. Oswald et al., 1957). The treatment system also succeeds to remove $40 \%-65 \%$ of COD, BOD and other impurities present in wastewater. The microalgae treatment system is economical, green, and environmental friendly option of wastewater treatment. Palmer (1974) surveyed microalgal genera from a wide distribution of waste stabilization ponds. In order of abundance and frequency of occurrence the algae found were Chlorella, Ankistrodesmus, Scenedesmus, Euglena, Chlamydomonas, Oscillatoria, Micractinium and Golenkinia (Palmer, 1974).

This paper aims to evaluate of the microalgae potential for commercial application, in particular to conduct experimental study of biogenic compounds removal from sewage waters by microalgae and to calculate economical benefits from biofertilizers and biofuel production.

\section{Methods and materials}

Two experimental sessions were held in the laboratory of the National Aviation University Faculty of Environmental Safety, Engineering and Technologies was chosen as the site of the experiment. For the experimental sessions, the summer period was chosen, since warm temperatures are more favorable for the growth of algae.

\section{Conditions for microalgae growing}

It was decided to use transparent bottles for growing microalgae to create the most favorable conditions for growing. The average temperature in the laboratory is $22^{\circ}$. The average pressure on the dates of the experiment was 746 millimeters of mercury. The concentration of microalgae is equal to 1 liter of water per $200 \mathrm{ml}$ of suspension of microalgae. The first experimental session included three parallel experiments for each type of water: one control without microalgae, one with wastewater and microalgae, one with a connected $\mathrm{CO}_{2}$ generator in wastewater with microalgae. The tanks were in a well-lit laboratory and had the same conditions. The second experimental session included four parallel experiments for one type of wastewater: the first control, the second in wastewater with microalgae, 3 and 4 identical samples with a connected $\mathrm{CO}_{2}$ generator.

\section{Measurement of nutrient rate}

To measure the levels of nutrients (phosphates, nitrates and nitrites), the following measurement frequency was chosen:

- in the first session - the first three days every day, then every two days; and

- in the second session - every 6 days.

\section{Experiment progress}

For the first experimental session, three reservoirs (bottles) were installed for each type of water (wastewater from a residential building in Kyiv before treatment, wastewater from a utility in Novograd-Volynsk before and after treatment). Totally 9 samples. The initial hypothesis was that the bulk of nutrients will go away in the first three days, so measurements of nutrient levels were carried out for the first three days every day, and then every two days. Immediately after the installation of all tanks, phosphate, nitrate and nitrite levels were measured to record the initial data.

To take measurements, it is necessary to follow this order: 
- to take an equal sample volume for all experiments;

- to carry out a double filtration with paper filters (first time through a funnel with a filter, and separately a second time through a funnel with a filter);

- gently wash the cuvettes with distilled water and wipe the cuvettes without touching the walls with your fingers so as not to create an error in the measurement;

- to take the necessary program on the spectrophotometer, and following the instructions add the reagent to the control sample;

- to record the result;

- to rinse the cuvettes with distilled water and take measurements for other samples of the experiment, also record the result; and

- at the end of the measurements, rinse all tubes, funnels and cuvettes with distilled water and dry.

For the second experimental session, four tanks were installed for one type of wastewater (wastewater from a residential building in Kyiv before entering the treatment plant): 1) control, 2) with microalgae, 3) and 4) identical with the connected $\mathrm{CO}_{2}$ generator. As the initial hypothesis was not confirmed, it was decided to take measurements every six days. The measurement progress remained the same as in the first session.

\section{Results and discussion}

As a result of our experiments the ability of microalgae to reduce biogenic elements in wastewater was confirmed. In Figure 1, the results of measurement are presented.

Table 1 demonstrates positive effect of microalgae in the case of nitrogen and phosphorous concentration.

The results of the study show that the content of nitrogen and phosphorus compounds significantly decreased, indicating the effectiveness of post-treatment of effluents using chlorella microalgae. Prospects of the microalgae use for wastewater treatment from nutrients are obvious. They are specially adapted to an environment dominated by viscous forces.

Figure 1 Nitrogen and phosphorus compounds concentration changes in wastewater

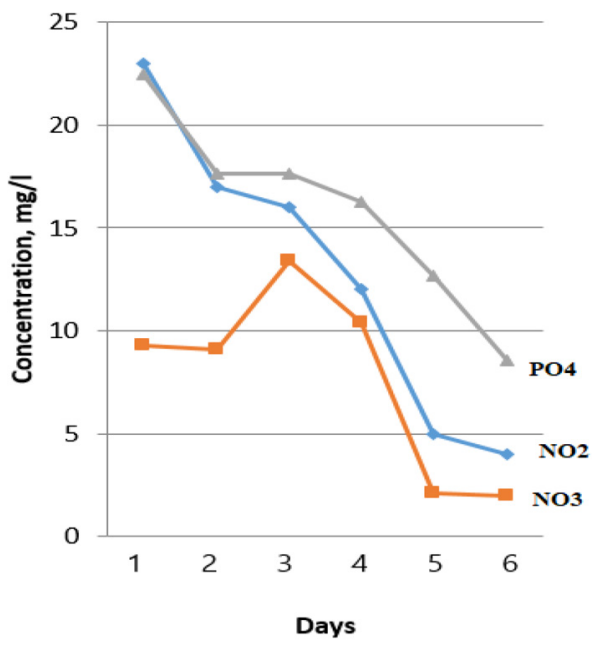

Table 1 Decreasing of biogenic compounds in wastewater

\begin{tabular}{lccc}
\hline Compounds & \multicolumn{2}{c}{ Concentration, $\mathrm{mg} / \mathrm{l}$} \\
Initial & Final & Decreasing, \% \\
\hline $\mathrm{NO}_{2}$ & 23 & 4 & 82.6 \\
$\mathrm{NO}_{3}$ & 9.3 & 2 & 78.5 \\
$\mathrm{PO}_{4}$ & 22.49 & 15.55 & 30.9 \\
\hline
\end{tabular}

\section{Practical implications}

Two types of waste water were talking into account by us: municipal and brewery waste waters.

Municipal treatment facilities.

A person consumes 200 liters per day of water for various needs. Ukraine has a population of 42 million, of which $69 \%$ are urban $\rightarrow 29$ million residents who use municipal treatment facilities.

Hence, for the past $24 \mathrm{~h}$, the urban population in Ukraine uses $5.8 \times 10^{9}$ 1. After water purification now contains $4.64 \times 10^{10} \mathrm{mg} / \mathrm{l}$, and after purification microalgae will be $8.7 \times 10^{9} \mathrm{mg} / \mathrm{l}$. That is, it is lost in Ukraine in a day irreversibly 37.7 tons of phosphates, causing irreparable damage to the environment, this year $3,760 \mathrm{t}$.

In phosphate fertilizer $50 \%$ of phosphates, which means that of 13,760 tons of phosphates we get 27520 tons of fertilizer.

1 ton of phosphate fertilizer costs $25,000 \mathrm{UAH} \rightarrow 27,520$ tons $\times 25,000 \mathrm{UAH}=688 \times 10^{6} \mathrm{UAH}=22640 \times 10^{6} \mathrm{EUR}$ is the profit that the state can get by applying this technology at municipal treatment plants.

\section{Brewery treatment facilities.}

Water consumption in Ukrainian breweries is 55 million $\mathrm{m}^{3}$ per year. In brewery wastewater has the highest content of phosphorus compounds $-19 \mathrm{ml} / \mathrm{l} \rightarrow 1045000 \mathrm{~kg}(1045 \mathrm{t}$ ) of phosphorus is released annually. Microalgae will delay 869 tons, i.e. reduce emissions by 6 times. From 1 ton of phosphates -2 tons of fertilizers. One ton of phosphate fertilizers costs 25 000UAH. Profit per year $-43,450000$ $\mathrm{UAH}=1,448,333$ EUR.

\section{Economic benefit from the biomass utilization as biofuel production}

The average annual productivity of the growth of microalgae by biomass, when cultivated in a photobioreactor in the weather conditions of Ukraine, can accept $11.5 \mathrm{~kg} / \mathrm{m}^{2}$ of the surface of the photobio-reactive zone (culture medium). In this case, the average lipid productivity will be $4.1 \mathrm{~kg} / \mathrm{m}^{2}$.

Provided that the waste water is in the working area of the photobioreactor as a medium for an average of 3 days, the total volume of photobioreactor working areas for cleaning the effluent of the urban population of Ukraine will be: $5.8 \times 10^{9} \times$ $3=17.4 \times 10^{9} 1$, or $17,4 \times 10^{6} \mathrm{~m}^{3}$.

If the thickness of the layer of effluents as a culture medium in the photobioreactor zone does not exceed $0.2 \mathrm{~m}$, then the total area of all photobioreactors should be:

$$
\sum S_{\text {bioreactor }}=\frac{17,7 \times 10^{6}}{0,2}=87 \times 10^{6} \mathrm{~m}^{2}
$$

Thus, the annual growth of biomass of algae can be: $M_{\text {biomass }}=$ $87 \times 10^{6} \times 11.5=1000.5 \times 10^{6} \mathrm{~kg}(2)$. The annual growth of 
lipids in this will be: $M_{\text {lipid }}=87 \times 10^{6} \times 4.1=$ $356.7 \times 10^{6} \mathrm{~kg}(3)$.

Under real conditions, with the effective removal of algae biomass from wastewater $90 \%$ (data for centrifugation), the efficiency of separating lipids from biomass of algae by $90 \%$, as well as the energy efficiency of processing lipids in biofuels, $90 \%$ of the annual mass of biofuel produced can be:

$$
\begin{aligned}
& M_{\text {biofuel }}=356.7 \times 10^{6} \times 0.9 \times 0.9 \times 0.9=\quad \mathrm{kg} \\
& 260.0 \times 10^{6}
\end{aligned}
$$

Given that the density of biodiesel is $0.86 \mathrm{~kg} / 1$, the volumetric amount of biodiesel produced will be:

$$
W_{\text {biofuel }}=\frac{260.0 \times 10^{6}}{0.86}=302.4 \times 10^{6} \text { liters } .
$$

Accepting the price of one liter of biodiesel at the level of UAH 28 , the total annual profit from the sale of biodiesel will be:

$$
\begin{gathered}
\Pi_{\text {biofuel }}=302.4 \times 10^{6} \times 28=8466.2 \times 10^{6} \\
\mathrm{UAH}=282.2 \times 10^{6} \mathrm{EUR}
\end{gathered}
$$

After this calculation we can conclude that the positive benefit after applying the chances are better than even. Diagram 1 presents the economic benefit from the biomass usage (Figure 2).

As we can see, there are many positive effects of microalgae application. Microalgae is very promising way from the commercial, energy and environmental points of view. That is why they are so attractive for many scientists in the world. In the case of environmental safety, microalgae can be used for protection of all components of the biosphere (Figure 3).

\section{Conclusion}

As a result of experimental studies the concentrations of nitrogen and phosphorus compounds in waste water were decreased: $\mathrm{NO}_{2}$ - by 5.75 times; $\mathrm{NO}_{3}$ - by $4.65 ; \mathrm{PO}_{4}$ - by 1.45 times.

Insufficient waste water treatment by municipal facilities leads to phosphates lost. The urban population in Ukraine uses $5.8 \times 10^{9} 1$ per $24 \mathrm{~h}$. Thus, in Ukraine in a day irreversibly 37.7

Figure 2 Economic benefit from biofuel and biofertilizer production

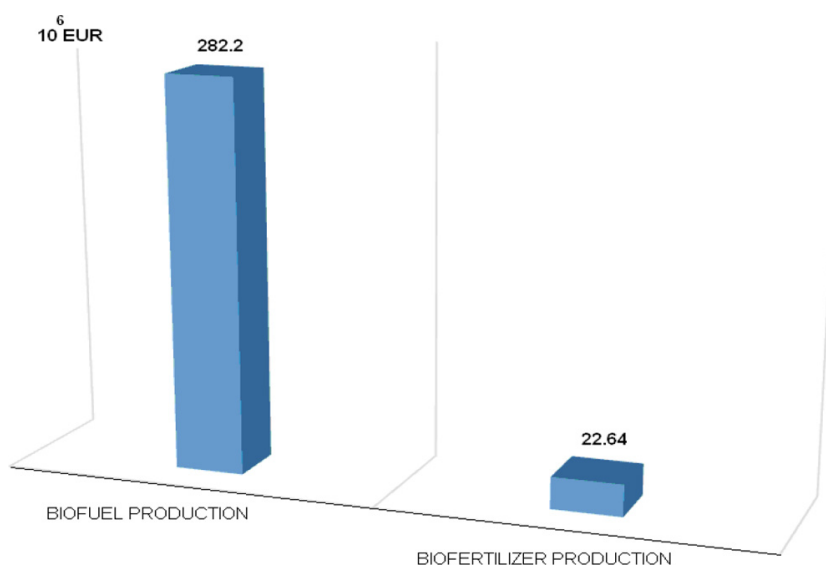

Figure 3 Microalgae application

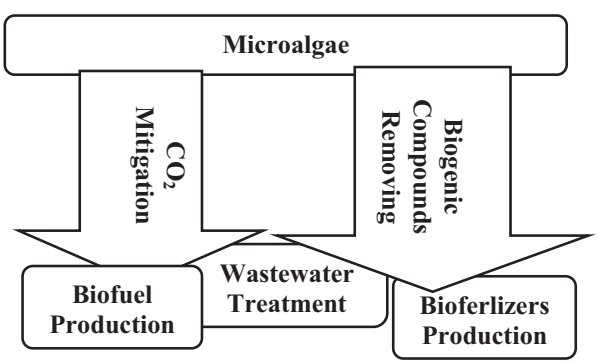

tons of phosphates, causing irreparable damage to the environment, this year 3,760 t. It means from 13,760 tons of phosphates we get 27,520 tons of fertilizer (profit -22 $640 \times 10^{6}$ EUR).

As was shown water consumption in Ukrainian breweries is 55 million $\mathrm{m}^{3}$ per year. It means $1045 t$ of phosphorus is released annually, microalgae will delay 869 tons, i.e. reduce emissions by 6 times. From 1 ton of phosphates -2 tons of fertilizers (profit - 1,448,333 EUR).

Due to calculations we can concluded that the annual mass of biofuel production (in the weather conditions of Ukraine) is $260 \times 10^{6} \mathrm{~kg}$ (profit $-282.2 \times 10^{6}$ EUR). The studying of microalgae, improvement of methods for their production, search for new ways of their processing, and thinking on new possibilities of how to use products made out of them form one of the most actively developing research directions in modern science. However, wastewater treatment by microalgae with further extraction for biofuel production demands the further investigations to improve existing technologies.

\section{References}

Bhagea, R., Bhoyroo, V. and Puchooa, D. (2019), "Microalgae: the next best alternative to fossil fuels after biomass", Microbiology Research, Vol. 10 No. 1, pp. 12-23., doi: 10.4081/mr.2019.7936.

Boichenko, M.S., Vovk, O.O., Boichenko, S.V. and Shamanskyi, S.I. (2018), "Perspectives of wastewater purification from biorezistant pharmaceutical products and biogenic elements", Energy Technologies and Resource Saving, Vol. 3, pp. 62-72., doi: 10.33070/etars.3.2018.04.

Bosma, R., van Spronsen, W.A., Tramper, J. and Wijffels, R.H. (2003), "Ultrasound, a new separation technique to harvest microalgae", Fournal of Applied Phycology, Vol. 15 Nos 2/3, pp. 143-153., doi: 10.1023/A:1023807011027.

Danilovich, D.A. (2012), "The best available technology for community sanitation", Water Supply and Sanitary Technique, Vol. 3, pp. 6-13.

Feofilova, E.P., Sergeeva, Y.E. and Ivashechkin, A. (2010), "Biodiesel-fuel: content, production, producers, contemporary biotechnology (review)", Applied Biochemistry and Microbiology, Vol. 46 No. 4, pp. 369-378., doi: 10.1134/S0003683810040010.

Gersberg, R.M., Elkins, B.V., Lyon, S.R. and Goldman, C.R. (1986), "Role of aquaticplants in wastewater treatment by artificial wetlands", Water Research, Vol. 20 No. 3, pp. 363-368.

Ghorbunova, S.J. (2007), "Dynamyka azota y fosfora v srede pry yntensyvnom kuljtyvyrovanyy mykrovodorosly dunaliella salina”, Эkologhyja Morja, Vol. 74, pp. 21-24. 
Głowacka, N. and Gaduš, J. (2019), "Verification of the green microalgae biomass use for biogas", Acta Regionalia et Environmentalica, Vol. 16 No. 1, pp. 15-49., doi: 10.2478/ aree-2019-0004.

Gonzalez Fernandez, C., Barreiro Vescovo, S., de Godos, I., Fernandez, M., Zouhayr, A. and Ballesteros, M. (2018), "Biochemical methane potential of microalgae biomass using different microbial inocula", Biotechnology for Biofuels, Vol. 11 No. 1, pp. 1-11., doi: 10.1186/s13068-018-1188-7.

Harun, R., Davidson, M., Doyle, M., Gopiraj, R., Danquah, M. and Forde, G. (2011), "Technoeconomic analysis of an integrated microalgae photobioreactor, biodiesel and biogas production facility", Biomass and Bioenergy, Vol. 35 No. 1, pp. 741-747., doi: 10.1016/j.biombioe.2010.10.007.

Healy, M. and Cawleyb, A.M. (2002), "Nutrient processing capacity of a constructed wetland in Western Ireland", Fournal of Environmental Quality, Vol. 31 No. 5, pp. 1739-1747., doi: 10.2134/jeq2002.1739.

Kadam, A., Oza, G., Nemade, P., Dutta, S. and Shankar, H. (2008), "Municipal wastewater treatment using novel constructed soil filter system", Chemosphere, Vol. 71 No. 5, pp. 975-981., doi: 10.1016/j.chemosphere.2007.11.048.

Koyandea, A.K., Show, P.L., Guob, R., Tangc, B., Oginod, C. and Chang, J.S. (2019), "Bio-processing of algal biorefinery: a review on current advances and future ", Bioengineered, Vol. 10 No. 1, pp. 574-592., doi: 10.1080/ 21655979.2019.1679697.

Lourenco, S.O., Barbarino, E., Mancini-Filho, J., Schinke, K. P. and Aidar, E. (2002), "Effects of different nitrogen sources on the growth and biochemical profile of 10 marine microalgae in batch culture: an evaluation for aquaculture", Phycologia, Vol. 41 No. 2, pp. 158-168., doi: 10.2216/i00318884-41-2-158.1.

Magdalena, J.A., Llamas, M., Tomas-Pejy, E. and GonzalezFernandez, C. (2019), "Semicontinuous anaerobic digestion of protease pretreated chlorella biomass for volatile fatty acids production", foumal of Chemical Technology \& Biotechnology, Vol. 94 No. 6, pp. 1861-1869., doi: 10.1002/jctb.5960.

Manigandan, S., Atabani, A.E., KumarPonnusamy, V. and Gunasekar, P. (2020), "Impact of additives in Jet-A fuel blends on combustion, emission and exergetic analysis using a micro-gas turbine engine", Fuel, Vol. 276, doi: 10.1016/j.fuel.2020.118104.

Manigandan, S., Atabani, A.E., Kumar Ponnusamy, V., Pugazhendhi, A. and Gunasekar Prakash, P.S. (2020), "Effect of hydrogen and multiwall carbon nanotubes blends on combustion performance and emission of diesel engine using Taguchi approach", Fuel, Vol. 276, doi: 10.1016/j. fuel.2020.118120.

Milledge, J.J., Nielsen, V., Maneein, S. and Harvey, P.J. (2019), "A brief review of anaerobic digestion of algae for", Energies, Vol. 12 No. 6, p. 22.

Molina Grima, E., Belarbi, E.-H., AciénvFernández, F.G., Robles Medina, A. and Chisti, Y. (2003), "Recovery of microalgal biomass and metabolites: process options and economics", Biotechnology Advances, Vol. 20 Nos 7/8, pp. 491-515., doi: 10.1016/S0734-9750(02)00050-2.

Naruka, M., Khadka, M., Upadhayay, S. and Kumar, S. (2019), "Potential applications of microalgae in bioproduct production: a review", Octa fournal of Biosciences, Vol. 7 No. 1, pp. 1-5.
Oswald, W.J., Gotaas, H.B., Golueke, C.G., Kellen, W.R., Gloyna, E.F. and Hermann, E.R. (1957), "Algae in waste treatment [with discussion] ", Sewage and Industrial Wastes, Vol. 29 No. 4, pp. 437-457.

Palmer, C.M. (1974), “Algae in American sewage stabilization ponds”, Rev. Microbiol, Vol. 5 No. 4, pp. 75-80.

Raheem, A., Prinsen, P., Vuppaladadiyam, A.K., Zhao, M. and Luque, R. (2018), "A review on sustainable microalgae based biofuel and bioenergy production: recent developments", fournal of Cleaner Production, Vol. 181, pp. 42-59., doi: 10.1016/j.jclepro.2018.01.125.

Reijnders, L. (2008), "Fuels for the future", Fournal of Integrative Environmental Sciences, Vol. 6 No. 4, pp. 279-794, available at: https://doi. org/10.1080/19438 150903068596

Saad, M.G., Dosoky, N.S., Zoromba, M.S. and Shafik, H.M. (2019), "Algal biofuels: current status and key challenges", Energies, Vol. 12 No. 10, pp. 1920, doi: 10.3390/en12101920.

Sasikanth, K., Jyotsna, T., Anjali, P. and Sharma, M.C. (2014), "Studies on cultivation of lipid accumulating botryococcus braunii from North Gujarat inland waters for generation of 3rd generation biofuels", Indian fournal of Applied Research, Vol. 4 No. 9, pp. 31-35.

Shamanskyi, S. and Boichenko, S. (2016), "Development of environmentally safe technological water disposal scheme of aviation enterprise", Eastern-European foumal of Enterprise Technologies, Vol. 6 No. 10, pp. 49-57., doi: 10.15587/17294061.2016.86053.

Shamanskyi, S.I. and Boichenko, S.V. (2018), "Chapter 11", in Hikmet Karakoç, T., Ozgur Colpan, C. and Şöhret, Y. (Eds), Environment-Friendly Technology of Airport's Sewerage. Advances in Sustainable Aviation, Springer International Publishing, pp. 161-175.

Shamanskyi, S.I. and Boichenko, S.V. (2018), Innovative Environmentally Friendly Technologies in Sewarage. Monograph. Kyiv: Publishing House, Center for Educational Literature, 320.

Shamanskyi, S.I., Boichenko, S.V. and Pavliukh, L.I. (2018), "Estimating of microalgae cultivation productivity for biofuel production in Ukraine conditions", Proceedings of the National Aviation University, Vol. 76 No. 3, pp. 67-77., doi: 10.18372/2306-1472.76.13161.

Sorokina, K.N., Yakovlev, V.A., Piligaev, A.V., Kukushkin, R.G., Peltek, S.Ye, Kolchanov, N.A. and Parmon, V.N. (2012), "The potential use of microalgae as raw material for bioenergy", Catalysis in Industry, Vol. 2, pp. 63-72.

Vandamme, D., Pontes, S.C., Goiris, K., Foubert, I., Pinoy, L. J. and Muylaert, K. (2011), "Evaluation of electrocoagulation-flocculation for harvesting marine and freshwater microalgae", Biotechnology and Bioengineering, Vol. 108 No. 10, pp. 2320-2329., doi: 10.1002/bit.23199.

Varfolomeev, S.D., Efremenko, E.N. and Krylova, L.P. (2010), Russian Chemical Reviews, Vol. 79 No. 6, pp. 491-509., doi: 10.1070/RC2010v079n06ABEH004138.

Veber, K. (1984), "Rost Chlorella vulgaris na stochnykh vodakh", Ghydrobyol. zhurn, Vol. 20 No. 1, pp. 32-40.

Williams, R. (2013), "Microscopic algae produce half the oxygen we breathe", available at: www.abc.net.au/radionational/ programs/scienceshow/microscopic-algae-produce-half-theoxygen-we-breathe/5041338. (accessed 29 April 2013). 


\section{Further readings}

Boichenko, S.V., Shamanskyi, S.I. and Adeniyi, C.O. (2019), "The estimation of microalgae productivity for biofuel production in Nigerian conditions", Science-Based Technologies, Vol. 41 No. 1, pp. 44-50., doi: 10.18372/2310-5461.41.13528.

Booma Devi, P., Joseph, D.R., Gokulnath, R., Manigandan, S., Gunasekar, P., Prem Anand, T.P., Venkatesh, S. and Vimal, M.R. (2019), "The effect of $\mathrm{TiO}_{2}$ on engine emissions for gas turbine engine fueled with jatropha, butanol, soya and rapeseed oil", International fournal of Turbo \& Fet-Engines, Vol. 37 No. 1, pp. 85-94., doi: 10.1515/tji-2019-9018.

Manigandan, S., KumarPonnusamy, V., BoomaDevi, P., YasinSohret, S.A., Venkatesh, S., RakeshVimal, M. and Gunasekar, P. (2020), "Effect of nanoparticles and hydrogen on combustion performance and exhaust emission of corn blended biodiesel in compression ignition engine with advanced timing", International fournal of Hydrogen Energy, Vol. 45 No. 4, pp. 3327-3339., doi: 10.1016/j.ijhydene. 2019.11.172.

Shamanskyi, S.I. (2018), "Evaluation of energy and economic efficiency of microalgae cultivation for biofuel production in Ukraine", Ecological Safety, Vol. 1 No. 25, pp. 52-60.

Shamanskyi, S. Boichenko, S. and Adeniyi, C. (2019), "Photobioreactor for microalgae cultivation for biofuel production with simultaneous sewage water treatment", Systemy i Ś rodki Transportu Samochodnego. Wybrane Zagadnienia. Monografia nr. 16. Seria: Transport. Rzeszów: Politechnika Rzeszowska, pp. 61-67.

\section{Corresponding author}

Lesia Pavliukh can be contacted at: lesiapavliukh003@ gmail.com 